\title{
Purification of TAXI-like Endoxylanase Inhibitors from Wheat (Triticum Aestioum L.) Whole Meal Reveals a Family of Iso-forms
}

\author{
KURT GEBRUERS*, HANS GOESAERT, KRISTOF BRIJS, CHRISTOPHE M. COURTIN and JAN A. DELCOUR \\ Laboratory of Food Chemistry, Katholieke Universiteit Leuven, Kasteelpark Arenberg 20, B-3001 Leuven, Belgium
}

(Received 8 December 2001)

\begin{abstract}
An affinity chromatography method has been developed for purification of endoxylanase inhibitors concentrated by cation exchange chromatography from wheat whole meal and is based on immobilisation of a Bacillus subtilis family 11 endoxylanase on $N$-hydroxysuccinimide activated Sepharose 4 Fast Flow. When followed by high-resolution cation exchange chromatography, the purification of seven TAXIs, Triticum aestivum L. endoxylanase inhibitors was achieved so extending the number of such proteins known to date (TAXI I and II). Based on their inhibition activities against a $B$. subtilis family 11 and an Aspergillus niger family 11 endoxylanase, six TAXI I- and only one TAXI II-like inhibitor could be distinguished. The first type of endoxylanase inhibitor is active against both endoxylanases and the second type only has significant activity against the $B$. subtilis endoxylanase.
\end{abstract}

Keywords: Affinity chromatography; Endoxylanase; Endoxylanase inhibitor; Biodiversity; Wheat

\section{INTRODUCTION}

The most abundant wheat (Triticum aestivum L.) nonstarch polysaccharide is arabinoxylan (AX). AX makes up $4-7 \%(\mathrm{w} / \mathrm{w})$ of the kernel weight and is partially soluble in water. The water extractable AX accounts for $0.3-1.2 \%(\mathrm{w} / \mathrm{w})$ of the kernel weight. ${ }^{1-3}$ AX is degraded by several xylanolytic enzymes, including endo- $\beta-1,4$-xylanases (endoxylanases, EC 3.2.1.8), $\beta$-D-xylosidases (EC 3.2.1.37) and $\alpha$-Larabinofuranosidases (EC 3.2.1.55). ${ }^{4}$ On the basis of amino acid sequence similarities, endoxylanases are mainly classified into two glycosyl hydrolase families, i.e. $10(\mathrm{~F})$ and $11(\mathrm{G}){ }^{5}$ both characterised by different molecular structures, relative molecular masses $\left(M_{\mathrm{r}}{ }^{\prime} \mathrm{s}\right)$ and catalytic properties. ${ }^{6,7}$ From a biotechnological point of view, endoxylanases, which hydrolyse internal $\beta-(1,4)$ linkages in the AX xylan backbone, are the most important xylanolytic enzymes since they have a profound impact on the functionality of AX. They are used in animal feed preparations, ${ }^{8}$ in industrial wheat gluten-starch separation, ${ }^{9}$ in paper and pulp production, ${ }^{10}$ as well as in bread-making. ${ }^{11-14}$

Quite recently, proteinaceous inhibitors of endoxylanases were detected in several cereals. ${ }^{15}$ To date, two types of endoxylanase inhibitors with different structures and specificities have been described. The first type is the TAXI ( $T$. aestivum $\mathrm{L}$. xylanase inhibitor)-like inhibitors. They are high pI, nonglycosylated proteins with $M_{\mathrm{r}}$ 's of approximately 40,000 and occur in two molecular forms. In the literature, a model is described according to which one of these forms is proteolytically derived from the other one ${ }^{15-20}$ At least two inhibitors of this type, TAXI I and II, are present in wheat ${ }^{17,20}$ and have varying specificities towards different endoxylanases. In rye (Secale cereale L.), a family of TAXI-like inhibitors has been demonstrated ${ }^{19}$ while at least one TAXI-like inhibitor exists in barley (Hordeum vulgare L.). ${ }^{18}$ The second type of endoxylanase inhibitors are non-TAXI-like proteins. They also have high pIvalues, but are monomeric glycosylated proteins with $M_{r}$ 's of approximately $30,000 .^{21,22}$ This type has been studied in wheat and rye. ${ }^{23}$ To date, the TAXIlike endoxylanases inhibitors are believed to be active against bacterial and fungal family 11

*Corresponding author. Tel.: +32-16-321634. Fax: +32-16-321997. E-mail: kurt.gebruers@agr.kuleuven.ac.be 
xylanases but not against family 10 xylanases, ${ }^{17-19}$ while the non-TAXI-like inhibitors have a specificity for fungal xylanases independent of the glycosyl hydrolase family to which these enzymes belong. ${ }^{24}$ However, to confirm the above suggested specificity, more endoxylanases need to be tested in this respect.

The present paper describes for the first time the development of a new elegant purification procedure for TAXI-like endoxylanase inhibitors from wheat whole meal based on affinity chromatography with immobilised bacterial (Bacillus subtilis) family 11 endoxylanase. It allows for fast large scale purifications of this type of endoxylanase inhibitor from different plant sources and has clear advantages over existing state of the art elaborate purification methods requiring much effort when large quantities of active protein are needed. ${ }^{17-19,21}$ We further demonstrate that, as is the case for rye, ${ }^{19}$ a family of TAXI-like endoxylanase inhibitors is also present in wheat.

\section{MATERIALS AND METHODS}

\section{Materials}

Wheat (Triticum aestivum L., var. Soissons, AVEVE, Landen, Belgium) was ground into whole meal using a Cyclotec 1093 sample mill (Tecator, Hogänäs, Sweden). A family 11 endoxylanase from Aspergillus niger and azurine cross-linked wheat AX (AZCL-AX) tablets were from Megazyme (Bray, Ireland). Grindamyl H 640 bakery enzyme, containing a B. subtilis family 11 endoxylanase (hereafter $B$. subtilis endoxylanase I) was made available by Danisco Cultor (Brabrand, Denmark). An A. aculeatus family 10 endoxylanase and a second similar $B$. subtilis family 11 endoxylanase (hereafter B. subtilis endoxylanase II) were kindly provided by NV Puratos (GrootBijgaarden, Belgium). All reagents, which were of analytical grade unless specified otherwise, and bovine serum albumin (BSA) were purchased from Sigma-Aldrich (Bornem, Belgium). All electrophoresis media, markers and chromatographic media were from Pharmacia Biotech (Uppsala, Sweden). The composition of the buffers used in this study is summarised in Table I.

\section{Protein Determination}

Protein concentration were determined by the Coomassie Brilliant Blue method of Bradford ${ }^{25}$ with BSA as standard.

\section{Endoxylanase Inhibition Assay Procedure}

The inhibition activities were determined with a variant of the xylazyme-AX method ${ }^{26}$ described by Gebruers et al. ${ }^{17}$ All endoxylanase solutions were prepared in buffer I and contained 2.0 enzyme units per $1.0 \mathrm{ml}$. One enzyme unit corresponds to an increase in absorbance at $590 \mathrm{~nm}\left(A_{590}\right)$ of 1.0 when the assay (see below) is performed in absence of endoxylanase inhibitor.

Endoxylanase solution $(0.5 \mathrm{ml})$ was pre-incubated for $30 \mathrm{~min}$ at room temperature with an equal amount of sample (in buffer I) to be tested for inhibition activity. The mixture was kept at $30^{\circ} \mathrm{C}$ and after 10 min an AZCL-AX tablet was added and the mixture then incubated for $60 \mathrm{~min}$ at $30^{\circ} \mathrm{C}$. The reaction was terminated by adding $1.0 \%(\mathrm{w} / \mathrm{v})$ Tris solution $(10.0 \mathrm{ml})$ with vigorous vortex stirring. After $10 \mathrm{~min}$ at room temperature, the tube was shaken vigorously and the content was filtered through a Schleicher and Schuell filter $(\phi 90 \mathrm{~mm})$ (Dassel, Germany). The $A_{590}$ value was measured against a control, prepared by incubating the sample with buffer instead of enzyme solution. The inhibition activity was expressed as a percentage decrease of the endoxylanase activity. One inhibition unit (IU) is defined as the amount of inhibitor resulting in 50\% inhibition of a given endoxylanase under the experimental conditions described above.

\section{Electrophoresis}

SDS-PAGE under non-reducing and reducing conditions was performed on $20 \%(\mathrm{w} / \mathrm{v})$ polyacrylamide gels with a Phast System unit (Pharmacia Biotech), as described in the Pharmacia Biotech separation technique file 110. 2-Mercaptoethanol [5\% $(\mathrm{v} / \mathrm{v})]$ was used as reducing agent. Low molecular mass markers were $\alpha$-lactalbumin $\left(M_{\mathrm{r}}=14,400\right)$, trypsin inhibitor $\left(M_{\mathrm{r}}=20,100\right)$, carbonic anhydrase $\left(M_{\mathrm{r}}=30,000\right)$, ovalbumin $\left(M_{\mathrm{r}}=43,000\right)$, albumin $\left(M_{\mathrm{r}}=67,000\right)$ and phosphorylase $\mathrm{b}\left(M_{\mathrm{r}}=94,000\right)$

TABLE I Composition of all buffers used

\begin{tabular}{|c|c|c|c|}
\hline Buffer & Composition & Buffer & Composition \\
\hline Buffer I & $\begin{array}{c}25.0 \mathrm{mM} \mathrm{NaOAc}, \mathrm{pH} 5.0 \\
0.5 \mathrm{mg} / \mathrm{ml} \mathrm{BSA}\end{array}$ & Buffer V & $25.0 \mathrm{mM} \mathrm{NaOAc}, \mathrm{pH} 5.0$ \\
\hline Buffer II & $25.0 \mathrm{mM}$ NaOAc, pH 4.0 & Buffer VI & $0.25 \mathrm{M}$ Tris, $\mathrm{pH} 12.0$ \\
\hline Buffer III & $\begin{array}{c}0.2 \mathrm{M} \mathrm{NaHCO}_{3}, \mathrm{pH} 8.3 \\
0.5 \mathrm{M} \mathrm{NaCl}\end{array}$ & Buffer VII & $25.0 \mathrm{mM} \mathrm{NaH}_{2} \mathrm{PO}_{4}, \mathrm{pH} 6.0$ \\
\hline Buffer IV & $\begin{array}{c}25.0 \mathrm{mM} \mathrm{NaOAc}, \mathrm{pH} 5.0 \\
0.2 \mathrm{M} \mathrm{NaCl}\end{array}$ & & \\
\hline
\end{tabular}


(Pharmacia Biotech). The $\mathrm{pI}$ values of the inhibitor proteins were determined by iso-electrofocusing and the $\mathrm{pH}$ stability of the endoxylanase-endoxylanase inhibitor complex was examined by titration curve iso-electrofocusing both as described in the Pharmacia Biotech separation technique file 100, utilising the same instrument with polyacrylamide gels containing ampholytes ( $\mathrm{pH} 3-9$ ). The broad range $\mathrm{pI}$ markers (3.5-9.3) of Pharmacia Biotech were used. All gels were silver stained as in Pharmacia Biotech development technique file 210 .

\section{Endoxylanase Purification}

B. subtilis endoxylanase I was purified from Grindamyl H 640. Portions thereof (20.0 g) were extracted for $2 \mathrm{~h}$ at room temperature with buffer II $(200 \mathrm{ml})$. This extract was dialysed against the same buffer $\left(18 \mathrm{~h}, 7^{\circ} \mathrm{C}\right)$ and subsequently centrifuged $\left(10,000 \mathrm{~g}, 30 \mathrm{~min}, 7^{\circ} \mathrm{C}\right)$. The endoxylanase was purified from this extract by means of cation exchange chromatography on a SP Sepharose Fast Flow column $(26 \times 300 \mathrm{~mm})$ using a gradient of $0.0-$ $0.5 \mathrm{M} \mathrm{NaCl}$ in $800 \mathrm{ml}$ and a flow rate of $5.0 \mathrm{ml} / \mathrm{min}$. Fractions of $10.0 \mathrm{ml}$ were collected, screened for endoxylanase activity using the xylazyme-AX method $^{26}$ and analysed with SDS-PAGE to assess the purity of the enzyme. Endoxylanase fractions with high purity were pooled, dialysed against deionised water and finally freeze-dried.

\section{Affinity Matrix Preparation}

$N$-hydroxysuccinimide activated Sepharose 4 Fast Flow matrix (Pharmacia Biotech) was used for the preparation of the affinity matrix with the freezedried B. subtilis endoxylanase I obtained above

Activated matrix $(7.0 \mathrm{ml})$ was transferred to a small column sealable at the top and bottom (column volume approximately $15.0 \mathrm{ml}$ ) and then the matrix was washed with a diluted $\mathrm{HCl}$ solution $(1.0 \mathrm{mM}$; $70.0 \mathrm{ml})$. Endoxylanase $(50.0 \mathrm{mg}$ ) was dissolved in buffer III $(7.0 \mathrm{ml})$. Just before coupling, the matrix was rinsed with the same buffer $(35.0 \mathrm{ml})$. The endoxylanase solution $(7.0 \mathrm{ml})$ was applied on top of the matrix and one half was allowed to flow into it. The column was sealed and the coupling was performed at room temperature for $2.5 \mathrm{~h}$ while shaking. After this incubation period, the excess endoxylanase was removed by rinsing with an ethanolamine solution $(0.5 \mathrm{M}, \mathrm{pH} 8.3,35.0 \mathrm{ml})$ containing $\mathrm{NaCl}(0.5 \mathrm{M})$. An additional amount $(5.0 \mathrm{ml})$ of the same ethanolamine solution was added, the column was sealed again and the mixture was incubated for $4 \mathrm{~h}$ at room temperature with vigorous shaking. The matrix was subsequently washed with glycine solution $(0.1 \mathrm{M}, \mathrm{pH} 3.0,35.0 \mathrm{ml})$ containing $\mathrm{NaCl}(0.5 \mathrm{M})$ and with the ethanolamine solution $(35.0 \mathrm{ml})$ described above. After equilibration with buffer IV $(70.0 \mathrm{ml})$, the affinity matrix was ready for use.

\section{Endoxylanase Inhibitor Purification and Biodiversity Analysis}

The TAXI-like endoxylanase inhibitors were purified using the affinity chromatography column described above following an initial separation step with cation exchange chromatography. A final step consisted of high resolution cation exchange chromatography which gave more insight into the biodiversity of the TAXI-like proteins within the wheat variety studied. After each purification step, the resulting fractions were assayed for endoxylanase inhibition activity against $A$. niger endoxylanase and $B$. subtilis endoxylanase II and the purity was checked with SDS-PAGE.

\section{Step 1: Preparation of Wheat Whole Meal Extract}

Wheat whole meal $(1.0 \mathrm{~kg})$ was suspended in $0.1 \%$ $(\mathrm{w} / \mathrm{w})$ ascorbic acid $(5.01)$, extracted overnight at $7^{\circ} \mathrm{C}$ and centrifuged $\left(10,000 \mathrm{~g}, 30 \mathrm{~min}, 7^{\circ} \mathrm{C}\right)$. To the supernatant, $\mathrm{CaCl}_{2}(2.0 \mathrm{~g} / \mathrm{l})$ was added and the $\mathrm{pH}$ was raised to 8.5 with $2.0 \mathrm{M} \mathrm{NaOH}$ to precipitate pectins. The extract was left overnight at $7^{\circ} \mathrm{C}$ and centrifuged $\left(10,000 \mathrm{~g}, 30 \mathrm{~min}, 7^{\circ} \mathrm{C}\right)$. The $\mathrm{pH}$ was adjusted to 5.0 with $2.0 \mathrm{M} \mathrm{HCl}$.

\section{Step 2: Concentration and Partial Purification by Cation Exchange Chromatography}

At $\mathrm{pH}$ 5.0, proteins with endoxylanase inhibition activity in the above wheat whole meal extract were retained by cation exchange chromatography on a SP Sepharose Fast Flow column $[26 \times 300 \mathrm{~mm}$, equilibrated with buffer $\mathrm{V}(500 \mathrm{ml})]$. A protein fraction was eluted in one step with $\mathrm{NaCl}$ solution $(0.5 \mathrm{M}, 500 \mathrm{ml})$, dialysed against deionised water $\left(48 \mathrm{~h}, 7^{\circ} \mathrm{C}\right)$ and freeze-dried.

\section{Step 3: Isolation of TAXI-like Endoxylanase Inhibitors by Affinity Chromatography With Immobilised}

\section{B. Subtilis}

\section{Endoxylanase I}

Portions of the freeze-dried material $(0.30 \mathrm{~g})$ were dissolved in buffer IV $(30.0 \mathrm{ml})$ and centrifuged $\left(10,000 \mathrm{~g}, 15 \mathrm{~min}, 7^{\circ} \mathrm{C}\right)$. The supernatant was loaded on the affinity column $[10 \times 70 \mathrm{~mm}$, previously equilibrated with the same buffer $(35.0 \mathrm{ml})]$ with immobilised B. subtilis endoxylanase I (flow rate $0.33 \mathrm{ml} / \mathrm{min}$ ). The column was rinsed with the cited buffer (seven column volumes). The bound proteins 


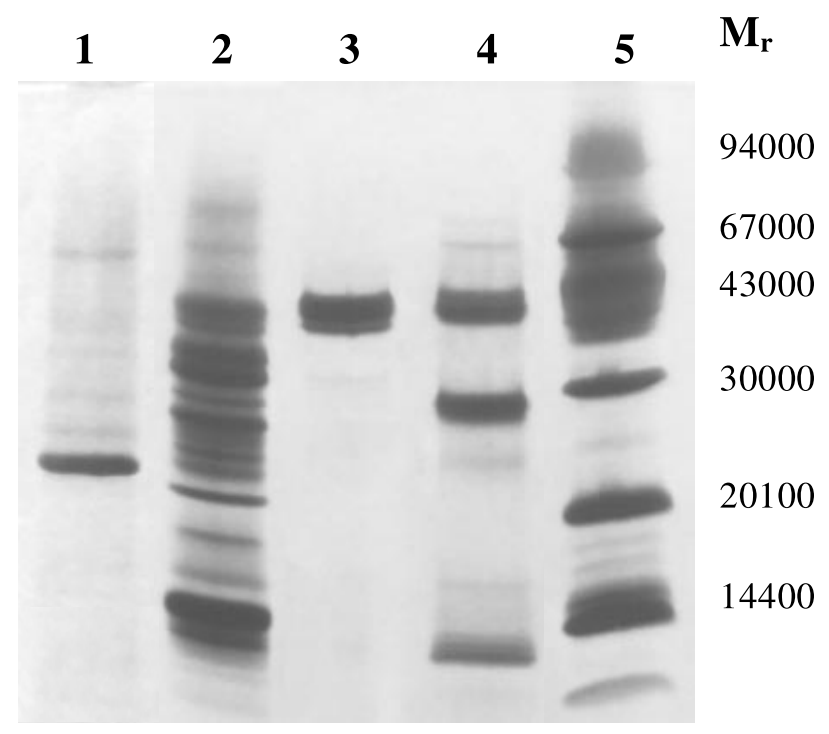

FIGURE 1 SDS-PAGE profiles of purified B. subtilis endoxylanase I (lane 1), protein fraction obtained from wheat whole meal by cation exchange chromatography on SP Sepharose Fast Flow (lane 2), TAXI-like endoxylanase inhibitors (non-reducing conditions: lane 3; reducing conditions: lane 4) obtained by affinity chromatography with immobilised B. subtilis endoxylanase I and low molecular mass markers (lane 5). The sizes of the markers are indicated at the right.

were eluted with buffer VI. The eluate was neutralised immediately with $1.0 \mathrm{M}$ acetic acid and dialysed against buffer VII. The resulting protein fraction consisted only of TAXI-like endoxylanase inhibitors as demonstrated with SDS-PAGE under reducing and non-reducing conditions (see below).

\section{Step 4: Separation of TAXI-like Endoxylanase Inhibitors by High Resolution Cation Exchange Chromatography}

The step 3 TAXI-like endoxylanase inhibitors $(1.0 \mathrm{mg}$ portions) were separated by cation exchange chromatography on a MonoS HR 5/5 column at $\mathrm{pH} 6.0$ (buffer VII), using a gradient of $0.0-0.5 \mathrm{M}$ $\mathrm{NaCl}$ in $100 \mathrm{ml}$ and a flow rate of $1.0 \mathrm{ml} / \mathrm{min}$. The proteins eluting at $\mathrm{NaCl}$ concentrations $0.045-$ $0.061 \mathrm{M}$ were separated again on the MonoS column using the same $\mathrm{NaCl}$ gradient and flow rate. However, this time, the separation was performed at $\mathrm{pH} 4.0$ (buffer II).

\section{RESULTS AND DISCUSSION}

\section{Endoxylanase Purification}

Purified B. subtilis endoxylanase I appeared as a single intense protein band on SDS-PAGE of approximately 24,000 (Fig. 1), indicating a high level of purity. This endoxylanase was immobilised on $N$-hydroxysuccinimide activated Sepharose 4 Fast Flow matrix in order to perform affinity
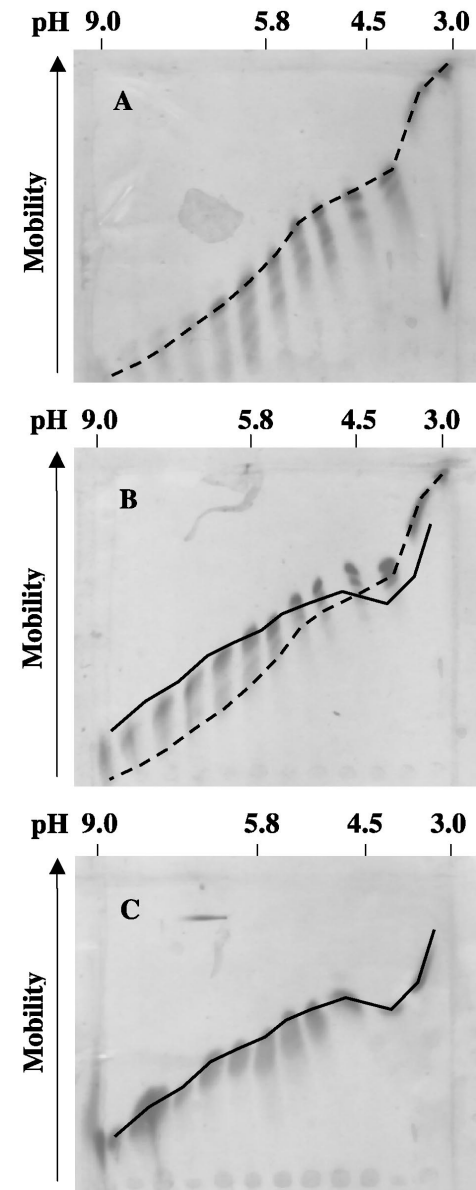

FIGURE 2 Titration iso-electrofocusing curves of TAXI-like endoxylanase inhibitor (A, dotted line), B. subtilis endoxylanase I-TAXI-like endoxylanase inhibitor complex (B) and B. subtilis endoxylanase I ( $C$, continuous line). In $B$, the inhibitor curve (dotted line) and endoxylanase curve (continuous line) are plotted over the complex curve.

chromatography to isolate TAXI-like endoxylanase inhibitors from wheat whole meal. To determine the proper $\mathrm{pH}$-conditions to be used for inhibitor elution the $\mathrm{pH}$-stability of the endoxylanase-endoxylanase inhibitor complex was studied.

\section{Titration Curve Iso-electrofocusing Analysis}

The stability of the endoxylanase-endoxylanase inhibitor complex in the range $\mathrm{pH} 3.0-9.0$ was assessed by titration curve iso-electrofocusing. To this end, iso-electrofocusing polyacrylamide gels containing ampholytes ( $\mathrm{pH} 3-9)$ were run in the absence of sample to build a $\mathrm{pH}$-gradient. The gels were then rotated $90^{\circ}$ and the actual separation was performed in a direction perpendicular to the $\mathrm{pH}$ gradient. TAXI-like inhibitor (Fig. 2A) (purified as described by Gebruers et al. ${ }^{17}$ ), B. subtilis endoxylanase I (Fig. 2C) and their complex (Fig. 2B), were separated in this way. The cited complex was prepared by mixing $B$. subtilis endoxylanase $I$ in buffer $\mathrm{V}$ with a quantity of TAXI-like inhibitor 


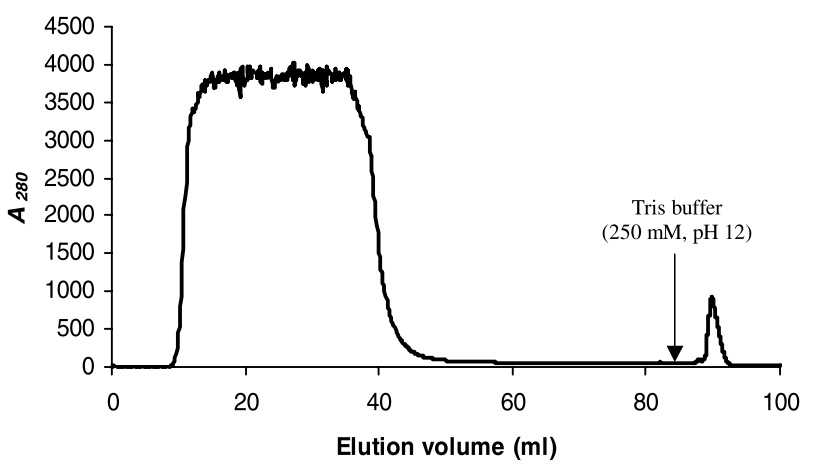

FIGURE 3 Affinity chromatogram corresponding with the purification of TAXI-like endoxylanase inhibitors by means of immobilised B. subtilis endoxylanase I. The elution volume at which the buffer was changed is indicated with an arrow. The protein material loaded on the affinity column was isolated from wheat whole meal with cation exchange chromatography on SP Sepharose Fast Flow.

sufficient for inhibiting the enzyme by approximately $80-85 \%$ followed by incubation at room temperature for $30 \mathrm{~min}$.

The titration curves of $B$. subtilis endoxylanase I and TAXI-like inhibitor intersect at approximately $\mathrm{pH}$ 4.5. Above this $\mathrm{pH}$-value, the latter curve shows the lowest mobility. The curve for the endoxylanaseendoxylanase inhibitor complex shows a somewhat higher mobility below $\mathrm{pH} 5.8$ and a somewhat lower mobility above $\mathrm{pH} 5.8$ than that of $B$. subtilis endoxylanase I. Below $\mathrm{pH} 4.5$ the $B$. subtilis endoxylanase I titration curve shows the lowest mobility and the other two curves behave rather similarly. Since the complex curve can be observed at all $\mathrm{pH}$-conditions tested, without any additional endoxylanase and/or inhibitor bands appearing, the endoxylanase-endoxylanase inhibitor complex is believed to be quite stable and more severe $\mathrm{pH}$-conditions have to be used for its dissociation.

\section{Endoxylanase Inhibitor Purification}

After extraction of wheat whole meal with $0.1 \%$ $(\mathrm{w} / \mathrm{v})$ ascorbic acid solution and concentration with cation exchange chromatography on SP Sepharose Fast Flow, a family of TAXI-like endoxylanase inhibitors was isolated by means of affinity chromatography with immobilised B. subtilis endoxylanase I (Fig. 3). To this end, small portions of the concentrated fraction were loaded on the affinity column at a low flow rate $(0.33 \mathrm{ml} / \mathrm{min})$ allowing the inhibitor and the endoxylanase to have sufficient time to interact. A considerable amount of $\mathrm{NaCl}$ was added to the running buffer solution to minimise a specific interactions of non-endoxylanase inhibitors with the matrix. After rinsing to remove noninteracting components, the bound proteins were eluted by raising the $\mathrm{pH}$ to 12.0 . This $\mathrm{pH}$-value was found most suitable for good elution. The eluted fraction consisted of TAXI-like endoxylanase inhibitors (SDS-PAGE, Fig. 1). Under non-reducing conditions, an intense band was noticed of approximately 40,000, while under reducing conditions two extra bands appeared of approximately 30,000 and 10,000, in agreement with Gebruers et al. ${ }^{17}$ for TAXI I and II, respectively. The latter two protein bands originate from proteolytically modified TAXI-like endoxylanase inhibitor.

The crude wheat whole meal extract $(1.0 \mathrm{~kg}$ meal per 5.01 extract) contained 166,820 and $138,560 \mathrm{IU}$ against $A$. niger endoxylanase $\left(\mathrm{IU}_{\mathrm{A} . n .}\right)$ and $B$. subtilis endoxylanase II (IU B.s.), respectively (Table II). Respectively, 35.3 and $36.8 \%$ of these activities were recovered in the affinity chromatography fraction, which had specific inhibition activities of 4,200 $\mathrm{IU}_{\text {A.n. }} / \mathrm{mg}$ protein and 3,640 IU $\mathrm{IB}_{\text {B.s. }} / \mathrm{mg}$ protein. These specific activities were respectively 144.8 and 151.7 fold higher than those in the crude whole meal extract. Approximately, $14 \mathrm{mg}$ of TAXI-like inhibitor was isolated from $1.0 \mathrm{~kg}$ of wheat whole meal.

TABLE II Purification of TAXI-like endoxylanase inhibitors from wheat whole meal monitored by assessment of total protein and of inhibition activity (IA) against $A$. niger endoxylanase (IA A.n.) and B. subtilis endoxylanase II (IA $\mathrm{B}_{\text {B.s. }}$ ). The specific activity, purification fold and recovery of endoxylanase inhibitor after each purification step are also included

\begin{tabular}{|c|c|c|c|c|c|}
\hline & $\begin{array}{l}\text { Total protein } \\
(\mathrm{mg} / \mathrm{kg} \text { meal) }\end{array}$ & $\begin{array}{c}\text { Total IA. } \\
\left(\mathrm{IU}^{*} / \mathrm{kg} \text { meal }\right)\end{array}$ & $\begin{array}{c}\text { Specific IA } \\
\text { (IU/mg protein) }\end{array}$ & $\begin{array}{l}\text { Purification } \\
\text { (fold) }\end{array}$ & $\begin{array}{l}\text { Recovery } \\
(\%)\end{array}$ \\
\hline \multicolumn{6}{|c|}{ Inhibition activity against $A$. niger endoxylanase ( $\left.\mathrm{IA}_{\text {A.n. }}\right)$} \\
\hline Crude extract & 5750 & 166820 & 29 & 1.0 & 100.0 \\
\hline CEC-fraction + & 2410 & 140240 & 58 & 2.0 & 84.1 \\
\hline AFC-fraction $\ddagger$ & 14 & 58820 & 4200 & 144.8 & 35.3 \\
\hline \multicolumn{6}{|c|}{ Inhibition activity against $B$. subtilis endoxylanase II (IA B.s. $\left._{\text {. }}\right)$} \\
\hline Crude extract & 5750 & 138560 & 24 & 1.0 & 100.0 \\
\hline CEC-fractiont & 2410 & 105550 & 44 & 1.8 & 76.2 \\
\hline AFC-fraction $\neq$ & 14 & 50990 & 3640 & 151.7 & 36.8 \\
\hline
\end{tabular}

${ }^{*} \mathrm{IU}$; the amount of inhibitor that inhibits 1.0 enzyme unit of $A$. niger endoxylanase of $B$. subtilis endoxylanase II by $50 \%$. ${ }^{\dagger}$ Protein fraction obtained from wheat whole meal extract with cation exchange chromatography on SP Sepharose Fast Flow. ${ }^{\ddagger}$ Protein fraction obtained from CEC-fraction with B. subtilis endoxylanase I affinity chromatography. 


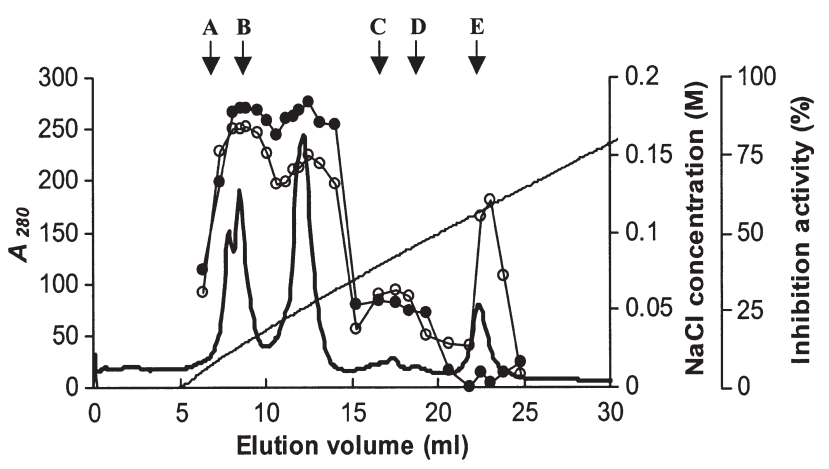

FIGURE 4 Cation exchange chromatogram (thick line, $A_{280}$ ) with reproduction of the $\mathrm{NaCl}$ gradient (thin straight line) corresponding with the separation performed at $\mathrm{pH} 6.0$ on MonoS of TAXI-like endoxylanase inhibitors obtained after affinity chromatography. The inhibition activities were measured against $A$. niger endoxylanase $(\bullet)$ and B. subtilis endoxylanase II $(O)$. The arrows (A to E) indicate the samples analysed by SDS-PAGE and iso-electrofocusing.

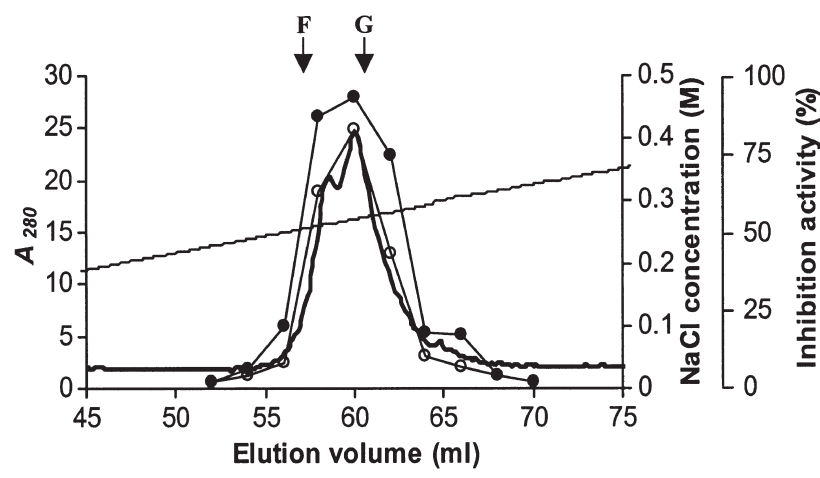

FIGURE 5 Cation exchange chromatogram (thick line, $A_{280}$ ) with reproduction of the $\mathrm{NaCl}$ gradient (thin straight line) corresponding with the separation performed at $\mathrm{pH} 4.0$ on MonoS of TAXI-like endoxylanase inhibitors which elute between $0.045-0.061 \mathrm{M} \mathrm{NaCl}$ at $\mathrm{pH}$ 6.0. The inhibition activities were measured against $A$. niger endoxylanase $(\bullet)$ and $B$. subtilis endoxylanase II $(O)$. The arrows (F and $G$ ) indicate the samples analysed by SDS-PAGE and iso-electrofocusing.

\section{Endoxylanase Inhibitor Characterisation}

Further analysis of the TAXI-like endoxylanase inhibitor fraction obtained after affinity chromatography with high resolution cation exchange chromatography showed four intense and two minor protein peaks (Fig. 4). Except for the inhibitor in the last protein peak, all other inhibitors were active against both $A$. niger endoxylanase and $B$. subtilis endoxylanase II. None of the inhibitors were active against $A$. aculeatus endoxylanase. The second protein peak showed a shoulder and was therefore separated again on the MonoS HR 5/5 column, this time at $\mathrm{pH}$ 4.0. This resulted in two protein peaks with a strong overlap (Fig. 5). For both separations, samples withdrawn during elution (indicated with arrows on Figs. 4 and 5) were analysed with SDSPAGE under reducing and non-reducing conditions as well as with iso-electrofocusing. All samples resulted in the above-cited SDS-PAGE profiles characteristic for TAXI-like endoxylanase inhibitors (Fig. 6). The pI-values of these inhibitors exceeded 8.0 (Fig. 7), the inhibitor corresponding to the first protein peak in Fig. 4 having the lowest and the one corresponding to the last protein peak having the highest value.

The present findings therefore show that wheat contains at least seven TAXI-like endoxylanase inhibitors (Figs. 4 and 5). Based on their activity against $A$. niger endoxylanase and $B$. subtilis endoxylanase II, six TAXI I-like and only one TAXI II-like endoxylanase inhibitors were observed. The first type is active against both endoxylanases and the second type only has significant activity against the $B$. subtilis endoxylanase II. Because of the similarity of their pI-values, the TAXI I-like endoxylanase inhibitor described by Gebruers et $a l^{17}$ may be one or a mixture of the inhibitors
A

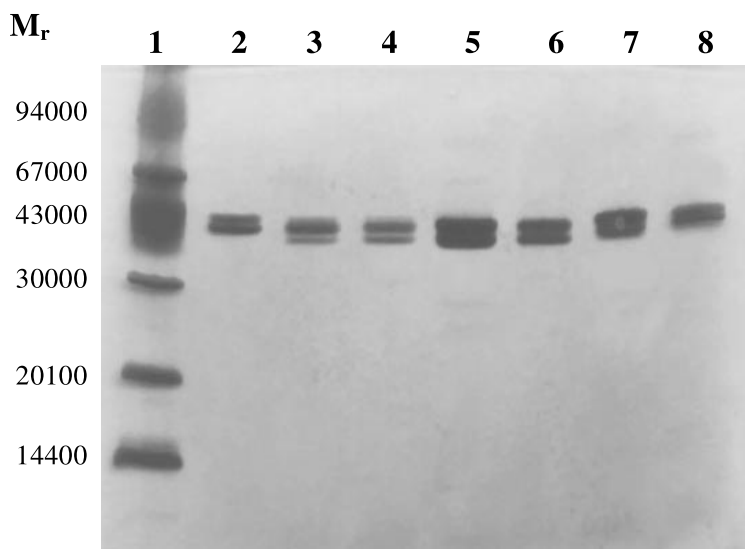

B

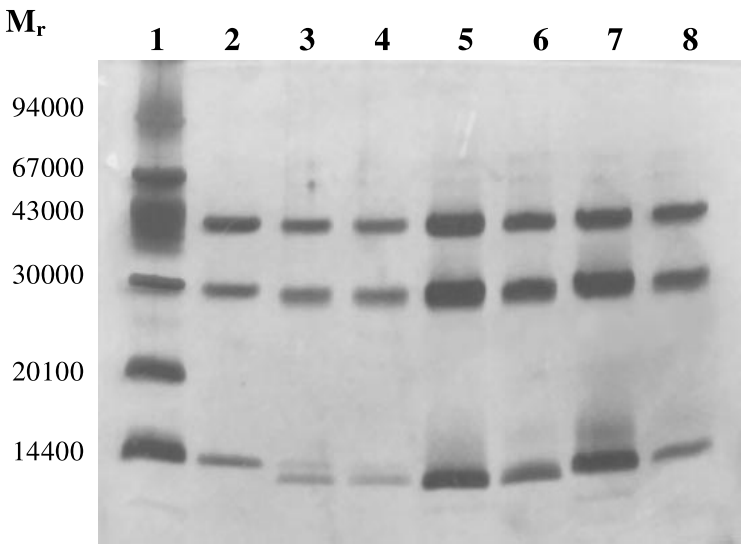

FIGURE 6 SDS-PAGE profiles of samples withdrawn during separation performed at pH 6.0 on MonoS of TAXI-like endoxylanase inhibitors: samples A (lanes 8), B (lanes 7), C (lanes 4), D (lanes 3) and E (lanes 2); and of samples during separation performed at pH 4.0 on MonoS of TAXI-like endoxylanase inhibitors which elute between $0.045-0.061 \mathrm{M} \mathrm{NaCl}$ at pH 6.0: samples F (lanes 6) and G (lanes 5) under reducing (A) and non-reducing (B) conditions. The sizes of the low molecular mass markers (lanes 1) are indicated at the left. 


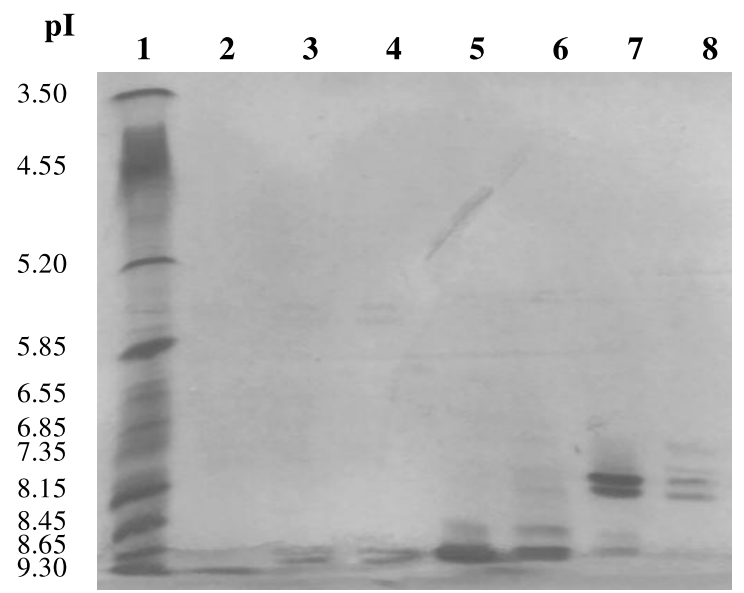

FIGURE 7 Iso-electrofocusing gel profiles of samples withdrawn during separation performed at $\mathrm{pH} 6.0$ on MonoS of TAXI-like endoxylanase inhibitors: samples A (lane 8), B (lane 7), C (lane 4), D (lane 3) and E (lane 2); and of samples during separation performed at $\mathrm{pH} 4.0$ on MonoS of TAXI-like endoxylanase inhibitors which elute between $0.045-0.061 \mathrm{M} \mathrm{NaCl}$ at $\mathrm{pH} 6.0$ : samples F (lane 6) and G (lane 5). The pI-values of the markers (lane 1) are indicated at the left.

corresponding to the third, fourth and fifth protein peaks in Fig. 4. However, taking into account there abundance in wheat and their elution behaviour in cation exchange chromatography on the MonoS HR $5 / 5$ column at $\mathrm{pH} 4.0$ (elution at $0.255-0.319 \mathrm{M}$ $\mathrm{NaCl}$ ), it is most likely that we earlier studied one or both of the inhibitors corresponding to the third protein peak in Fig. 4 (or both peaks in Fig. 5). Since only one TAXI II-like endoxylanase inhibitor was observed in this study, it is very likely that this is also the one studied by Gebruers et al. ${ }^{17}$

\section{CONCLUSIONS}

Here, for the first time is described a purification procedure for TAXI-like endoxylanase inhibitors based on affinity chromatography with immobilised endoxylanase and for the first time clearly demonstrates that there are at least seven such inhibitors in wheat. The B. subtilis family 11 endoxylanase I used had specific affinity for the TAXI-like inhibitors and quite severe alkaline conditions were needed to dissociate the complexes formed.

The purification procedures previously described in the literature $\mathrm{e}^{17-19}$ are rather time consuming since more steps are needed to obtain the pure endoxylanase inhibitors. For instance, in order to isolate TAXI I and II from wheat flour, Gebruers et al. ${ }^{17}$ had to perform seven purification steps. They also needed gel permeation chromatography, which was rather rate limiting. Another disadvantage of the earlier method is that it had to be optimised for every plant source examined. ${ }^{18,19}$
Affinity chromatography allowed us to isolate a mixture of seven TAXI-like endoxylanase inhibitors from wheat whole meal in only two steps without using gel permeation chromatography. The general recoveries of the inhibition activity against $A$. niger endoxylanase and $B$. subtilis endoxylanase II were 35.3 and $36.8 \%$, respectively, and the affinity chromatography fraction contained $4,200 \mathrm{IU}_{\mathrm{A} . n .} / \mathrm{mg}$ and $3,640 \mathrm{IU}_{\text {B.s. }} / \mathrm{mg}$ protein. $1.0 \mathrm{~kg}$ of wheat whole meal resulted in approximately $14 \mathrm{mg}$ of the TAXIlike inhibitor proteins, which can be at least partially separated with high resolution cation exchange chromatography. Based on their activity against the cited endoxylanases, six TAXI I- and only one TAXI II-like inhibitors could be distinguished. Because both the proteolytically as well as the nonproteolytically modified form of the TAXI-like endoxylanase inhibitors were retained on the affinity column, both forms probably have inhibitory activity. However, further studies are needed to determine their inhibition capacities.

The approach described in this paper provides an opportunity for a fast large scale purification of endoxylanase inhibitors from wheat and other plant sources, for which only minor adjustments will be needed. Based on the specificities of TAXI- and nonTAXI-like endoxylanase inhibitors, the use of other endoxylanases to perform affinity chromatography may result in the future discovery of different endoxylanase inhibitors.

\section{Acknowledgements}

Financial support was obtained from the "Onderzoeksfonds" (Leuven, Belgium), the "Fonds voor Wetenschappelijk Onderzoek-Vlaanderen" (F.W.O.Vlaanderen, Belgium) and from the Commission of the European Communities, Specific RTD programme "Quality of Life and Management of Living Resources", QLK1-2000-00811, "Solving the Problem of Glycosidase Inhibitors in Food Processing". This study does not necessarily reflect the views of the commission and its future policy in this area. Further financial support by the "Instituut voor de aanmoediging van Innovatie door Wetenschap en Technologie in Vlaanderen" (I.W.T, Brussels, Belgium) (scholarship to K. Gebruers and GBOU project funding) is gratefully acknowledged. Christophe M. Courtin is post-doctoral fellow of the "FWO-Vlaanderen".

\section{References}

[1] Henry, R.J. (1985), J. Sci. Food Agric. 36, 1243.

[2] Hashimoto, S., Shogren, M.D. and Pomeranz, Y. (1987), Cereal Chem. 64, 30.

[3] Girhammer, U. and Nair, B.M. (1992), Food Hydrocolloids 6, 285. 
[4] Biely, P. (1985), Trends Biotech. 3, 286

[5] Henrissat, B. (1991), Biochem. J. 280, 309

[6] Jeffries, T.W. (1996), Curr. Opin. Biotech. 7, 337.

[7] Biely, P., Vrsanska, M., Tenkanen, M. and Kluepfeld, D. (1997), J. Biotech. 57, 151.

[8] Bedford, M.R. and Classen, H.L. (1992) In: Visser, J., Beldman, G., Kusters-van-Someren, M.A. and Voragen, A.G.J., eds, Xylanas and Xylanases (Elsevier Science Publishers, Amsterdam, The Netherlands), pp 361-370.

[9] Christophersen, C., Andersen, E., Jacobsen, T.S. and Wagner, P. (1997), Starch/Stärke 1, 5.

[10] Suurnäkki, A., Tenkanen, M., Buchert, J. and Viikari, L. (1997), Adv. Biochem. Eng. Biotech. 57, 261.

[11] Courtin, C.M., Roelants, A. and Delcour, J.A. (1999), J. Agric. Food Chem. 47, 1870.

[12] Courtin, C.M., Gelders, G.G. and Delcour, J.A. (2001), Cereal Chem. 78, 564.

[13] Rouau, X., El-hayek, M.L. and Moreau, D. (1994), J. Cereal Sci. 19, 259.

[14] Hillhorst, R., Dunnewind, B., Orsel, R., Stegeman, P., van Vliet, T., Gruppen, H. and Schols, H.A. (1999), J. Food Sci. 64, 808.

[15] Debyser, W., Delcour, J.A. (1997). "Inhibitors of Xylanolytic and $\beta$-Glucanolytic Enzymes", Patent application WO98/49278.

[16] Debyser, W., Peumans, W.J., Van Damme, E.J.M. and Delcour, J.A. (1999), J. Cereal Sci. 30, 39.

[17] Gebruers, K., Debyser, W., Goesaert, H., Proost, P., Van Damme, J. and Delcour, J.A. (2001), Biochem. J. 353, 239.
[18] Goesaert, H., Debyser, W., Gebruers, K., Proost, P., Van Damme, J. and Delcour, J.A. (2001), Cereal Chem. 78, 453.

[19] Goesaert, H., Gebruers, K. and Delcour, J.A. (2002), J. Cereal Sci., in press.

[20] Debyser, W., Delcour, J.A., Fierens, K., Gebruers, K., Goesaert, H., Robben, J., Van Campenhout, S. (2001). "Biocatalyst Inhibitors", Patent application WO 01/98474.

[21] McLauchlan, W.R., Garcia-Conesa, M.T., Williamson, G., Roza, M., Ravestein, P. and Maat, J. (1999), Biochem. J. 338, 441.

[22] Hessing, M., Happe, R.P. (2000). "A Novel Class of Xylanase Inhibitors", European Patent EP 0979830 A1.

[23] McLauchlan, W.R., Flatman, R.H., Sancho, A.I., Kakuta, J., Faulds, C.B., Eliot, G.O., Kroon, P.A., Furniss, C.S.M., Juge, N., Ravestein, P. and Williamson, G. (2000) In: Simoinen, T. and Tenkanen, M., eds, Proceedings of The Second European Symposium on Enzymes in Grain Processing, Helsinki, (1999) (VTT Technical Research Centre, Finland), pp 55-61.

[24] Flatman, R., McLauchlan, W.R., Berrin, J.-G., Juge, N., Furniss, C., Manzanares, P., Gilbert, H., Clarke, A., Davies, G., Ladbury, J. and Williamson, G. (2001) "Specificity of a Xylanase Inhibitor towards Xylanase", The Fourth Carbohydrate Bioengeneering Meeting, Stockholm (2001) (Royal Institute of Technology, Sweden), Poster presentation.

[25] Bradford, M.M. (1976), Anal. Biochem. 72, 248.

[26] McCleary, B.V. (1992) In: Visser, J., Beldman, G., Kusters-vanSomeren, M.A. and Voragen, A.G.J., eds, Xylanas and Xylanases (Elsevier Science Publishers, Amsterdam), pp $161-170$. 